\section{International Scientific Journal Theoretical \& Applied Science}

p-ISSN: 2308-4944 (print) e-ISSN: 2409-0085 (online)

Year: $2016 \quad$ Issue: $11 \quad$ Volume: 43

Published: 17.11.2016 http://T-Science.org
Azer Nadir ogli Adigezalov Head teacher of the chair of "History of Uzbekistan" of Andizhan State University

Dilyor Kozimjon ogli Abidov Andizhan State University`s student of Historical Faculty Andizhan, Uzbekistan Azerbay23@mail.ru

SECTION 13. Geography. History. Oceanology. Meteorology.

\title{
ORIENTATION REASONS OF TURKESTAN'S DJADIDISM TOWARD PANTURKISM AND POLITICAL PROCESSES IN AZERBAIJAN
}

Abstract: In this article the information about coming into being and forming of the Djadid's movement in Turkestan and its collaboration with Azerbaijan's political parties, and also about the orientation toward panturkism and panislamism is given.

Key words: Djadid's movement, Turkestan, Azerbaijan`s political parties, panturkism, panislamism, Shuroyi islomiya, Shuroyi ulamo, Union of Turkestan muslims.

Language: English

Citation: Adigezalov AN, Abidov DK (2016) ORIENTATION REASONS OF TURKESTAN'S DJADIDISM TOWARD PANTURKISM AND POLITICAL PROCESSES IN AZERBAIJAN. ISJ Theoretical \& Applied Science, 11 (43): 73-76.

Soi: http://s-o-i.org/1.1/TAS-11-43-14 Doi: crossef http://dx.doi.org/10.15863/TAS.2016.11.43.14

\section{Introduction}

Djadidism, which sprang up like an educational movement on the boundary of XIX-XX centuries and disappeared at the end of the 1920s exposed to attack of Soviet rule, still arouses great interest not only in Middle Asia, but also far from its bounds.

It should be mentioned that it was originally limited cultural movement of new methods, for the necessity of European education for Turkestan's Muslims. Moreover, it was exceptionally of legal nature. This movement arose among Tatar bourgeoisie in the Crimea, the Volga region and in Azerbaijan in the 80s of the XIX century [1].

\section{Materials and Methods}

I.Gasprinsky, a Crimean Tatar, murzak and a prominent landowner, who was publishing "Tarjiman" ("Translator") newspaper in Bakhchisaray in 1883-1914, was the founder and an active propagandist of Djadidism. The foundation and development of an educational movement of Islamic East people - djadidism (new, more refined teaching method), which radically changed the essence and the structure of elementary education in many Muslim countries, having given it more refined nature, is connected with his name. The fundamentals of Muslims' ethno- confessional national education system's transformation were worked out by I.Gasprinsky. In the schools of new method children were taught according to the sound method new for Muslims. From the beginning of the XX century in this schools the textbooks of local authors began to be used equally with the textbooks made by Azerbaijanis, Tatars, Turks and Persians [2].

In its development djadidism passed 2 stages: the first one is an educational stage and the second one is political. However, Djadids' views on the statehood matters began to form at the first stage already, and at the second one they had already found their complete form.

Djadids directed their attention to Turkish panturkists, close ties with Tatar and Azerbaijani panturkists. It should be mentioned, that an Azerbaijani S.M.Ganizade ${ }^{1}$ took an active part in creating the new method schools in Turkestan. In 1893 in Samarkand the first in these parts new method school was opened by him [3]. Then such schools began to function in other cities of Turkestan.

1 Ganizade Sultan Medjid Gadji Murtuzali ogly (1866-1937) is a famous Azerbaijani enlightener, pedagogue. He was occupied with compilation of textbooks, dictionaries and maps, was the author of educational methodological aids and fiction equally with his pedagogical activity. 
At the same time djadids were tsarism campaigners in fact and tried to keep the masses from revolutionary appearances. The social base of djadidism was mainly bourgeois sections of the population of Middle Asia and a part of national professional classes (intelligentsia).

The leaders of Middle Asian djadidism were Makhmud-khodja Behbudi, Munavvar-Kary Abdurashidov, Abdurauf Fitrat, Ubaydulla Khodjayev (Turkestan), Fayzulla Khodjayev (Bukhara), Palvan-Niyaz Khodji-Yusupov (Khiva) [4].

In Makhmudkhodja Behbudi's opinion the colonial system made people of Turkestan live according to European laws which they didn't know and to protect their rights they needed to be educated. I.M.Behbudi came to conclusion that highlyeducated specialists, lawyers, in particular, could be of use to the nation, operating through the State Duma, courts and official organs of Russian administration in Turkestan. Thus, in 1913 already he brought forward the following theory: enlightenment and education development among Turkestan people is necessary for protection of their national and state interests [5].

The problem of all peoples' of Turkestan unity made the main part of the conception as they connected the future state system with their solidarity. If we draw a parallel, then we can come to similarity with Musavat's activity in Azerbaijan, when after Islamic unity the party began the process of political line evolution towards national concepts [6]. It is testified by international links of djadids by means of which they aware of the djadids movement's programs not only of Russia, but also of Turkey, Egypt, exchanging their experience by means of journeys and conversations.

Thus, such publications as "Sarvati funun", (" Fine handicraft", Istanbul), "Habl ul-matin" ("Firm bonds", Calcutta), "Chehranamo" ("Mirror", Alexandria), "Parvarish" ("Up-bringing", Cairo) spread over Turkestan after the year of 1905 and also "Iqbal" ("Happiness", Baku), "Molla Nasretdin" (Tiflis), "Vaqt" ("Time" Orenburg), "Shuro" ("Advice", Ufa) and others spread in 1914-1915s played a certain role in Uzbek djadids' coming into being and forming too.

The revolution events of 1905-1906s in Russia brought their pressure to bear also upon Turkestan.

Djadids, like liberal forces of Azerbaijani national movement, tried to achieve their goals in peaceful and legal ways through appeals to the State Duma. Tsarist administration, which worried about the rise of local population's political consciousness, vetoed the presence of the representatives in the Duma, but it related to all Turkic nationalities.

Then djadids came to the conclusion of the necessity to unite and create a unified Muslim party in order to form a part of All-Russian Muslim's union. In the article, published in "Khurshid" newspaper of October 11, 1906, M.Bekhbudi wrote that only in this way, depending on progressive forces of Turkic nationalities in Russia they could achieve political rights. At this point he expressed his negative relation to social-democratic party, considering its program unacceptable for Muslims' life norms and a utopian one.

The revolutions which took place in 19051911s in Turkey and Iran had appreciable influence on Central Asian djadidism. The representatives of national professional classes of these countries pursued a goal to restrict monarchic power by means of constitutional limits and to strengthen economical might of national bourgeoisie, having created appropriate conditions and prerequisites for it.

Before 1917 Middle Asian djadidism couldn't gain certain organizational forms. They called djadids those people, who spoke for the necessity to liquidate some feudal vestiges which were inconvenient for arising bourgeoisie, for limited reform of Islam and religious schools, for Islam's adaptation for bourgeois development of national borders of Russian Empire and the national bourgeoisie's needs. But djadids didn't have a certain program as well as steering centre and regulations. They grouped around separate djadids' publishing houses of newspapers and magazines which were published legally in Turkestan and Bukhara new method schools, charity societies.

The day before democratic revolution in February djadidism of Turkestan had already constituted a serious political power. If after World War I djadids struggled for parliamentary monarchy, then after the revolution in February their radical part brought forward more extensive number of demands, among which there was putting deep reforms(into effect) on widening of local population's proxies in land government, apportionment of posts in the State Duma, proceeding from factual numbers of local population, provision of basic democratic freedoms and, first and foremost, freedom of the national press, monarchic system replacement by constitutional one.

This is clearly reflected in M. Bekhbudi's article, who wrote: "There will be a big Centre (Markaz) and a Meeting (Majlis) in Tashkent where several people who will have been chosen from five vilayats (regions) of Turkestan from every town and uyezd will enter. The legislation and law-abidance of all the tax-payment processes must be on their authority. This Majlis will be an intermediary between Russian government and Muslims. They will support every guardian (vali) and bailiff (mamur) from Turkestan and from every region (vilayat), and will work actively for Turkestan's progress and for its development. It is natural, that sworn attorneys (vakils) and deputies (mabuses) for the most part should be from Muslims and for the least part from Russians, and the cause should not be 
done by order or a violent method, but concertedly". However, in order to get rights, in M. Bekhbudi's opinion, it was necessary to enter into social struggle more actively, irrespective of their nationality and having united with Russian people, they needed to organize "The Union of Turkestan Muslims", having elected representatives from every uyezd there -these were the first stipulations to freedom and independence. He considered that the main term for autonomous existence within the framework of democratic state of Russia was the elimination of internal conflicts [7].

From the $1^{\text {st }}$ till the $11^{\text {th }}$ of 1917 there took place the First All-Russian congress of Muslims in Moscow. Serious disagreements were exposed on the point about the form of Russian national and state system. Its discussion led to the forum's division into two big groups: one of them depended on the principles of centralism and was coming out in favour of exterritorial cultural autonomy of Muslims consisting of democratic republic, and the other was coming out in favour of territorial autonomy consisting of Russian federation. The first ones' position was stated in Akhmed Tsalikov's resolution, and the second ones' one was stated in M.A.Rasulzade's revolution.

After impetuous and long debates (446-for, 271-against)Rasul-zade's resolution was adopted by majority. It recognized the democratic republic on national-territorial federation basis, in the first place, while the nationalities, which didn't have a certain territory, made use of national-cultural autonomy. In the second place, a Central common to all Muslims organ for the whole Russia with legislative functions in this region was established for regulation of common religious cultured points of Muslims of Russia and those who were at one with their appearances. The form, structure and functions of this organ are determined by the first constituent congress of all autonomous units' representatives [8].

In Turkestan national political parties and unities began to spring up, in particular, in March, 1917 djadids formed an organization "Shuroyi islomiya", where the representatives of clergy and other social sections of the population entered too. By that time djadids managed to distract different social sections from the local population, having aroused in people's inquiry the aspiration to unification.

However, soon they realized that both Temporary Russian government and Temporary committee in Turkestan continued to conduct in the country, as it had been before, the same colonial politics. It obviously pointed to the necessity to hold a constituent assembly. Since that time the problem of gaining the autonomy and independence grew into the matter of life and death for the progress makers, as a result embittered political battles began.
In June 1917 "Shuroyi islomiya" went out from the organization and created its own organization "Shuroyi ulamo" [9]. In August 1917 the elections to the State Duma of Turkestan were held. In many of them the organization "Shuroyi islomiya" got the majority of voices. On the elections to Tashkent Duma "Shuroyi ulamo" got the majority of places: it got 62 places from 112, social-democrats-5, SRs-24, "Shuroyi islomiya"-11, altogether 74 ones were open, from the local population, and 38 ones from the European population [10].

Trying to neutralize the influence of Bolsheviks and realizing the necessity of national movement's strengthening, the progress makers made a decision about the unification of "Shuroyi ulamo" and "Shuroyi islomiya" into the united party named "Turk Adami markaziyati".

During the period of preparation to the convocation of constituent assembly the movement became of the nature of struggle for independence. Djadids who realized that the moment of acute struggle for independence and autonomy, began to expose colonialism to sharp criticism, completely turned down the previous idea of constitutional monarchy and came out in favour of affording to Turkestan the national territorial autonomy forming a part of Russian Federation Democratic Republic.

In programme documents of progress makers main attention was paid to working out the mechanisms of national-territorial autonomy's realization principles, in particular, to organization of supreme authority organs, government and the country court of law, which were called to carry out independent power of Turkestan. Priority aim of progress makers was democratic society forming, where democratic rights and freedoms had to be conceded and constitutionally guaranteed. Their unquestionable contribution was bringing forward the idea of all nations and nationalities inhabiting Turkestan at that time equality in the face of law in all the spheres of economic, socio-political, legal and cultural life. It should be noted, that Turkestan's djadids connected the realization of their state independence ideas with the peace and agreement between different social powers of the country. They applied much force and energy for getting places in Constituent assembly.

October events in Turkestan and capture of power by Bolsheviks didn't allow them to achieve aspired aims. But, in spite of this, djadids declared about creating an independent autonomous republic named "Turkiston Muhtoriyati" in Kokand, having used their rights which were proclaimed by new forces of Bolsheviks about national selfdetermination.

On November 27, 1917 on the IV extraordinary All-muslim congress held in Kokand, it was declared about Turkestan autonomy creating ("Turkiston Muhtoriyati"), led by Turkestan Temporary Council, 
which was headed by Mukhamedjan Tanyshbayev. Mustafa Shokay headed Ministry of Foreign Affairs, but soon in connection with Tanyshbayev's leaving because of internal disagreements he became the chairman of the government. Kokand's government announced about the intension to call on March 20, 1918 its parliament on the basis of universal direct, equal and secret suffrage. Two third of the places in the parliament was intended for Muslim deputies, and one third was intended for the representatives of non-Muslim population. The existence of such parliament had to become the first step to Turkestan's democratization. By the way, in Turkestan Soviet Republic (TASSR) formed at the same time, not one in 14 of its members was the representative of local nations.

In January, 1918 Shokay refused to recognize their authority in reply to the ultimatum brought forward by Soviets. 11 echelons with troops and artillery came to Tashkent from Moscow to wipe out Turkestan autonomy. Red Army of Tashkent garrison and Armenian dashnaks became members of the punitive detachment.

On February 6, 1918 Bolsheviks began the assault of Kokand and in 3 days they completely destroyed the ancient town. The republic existed only 72 days and was destroyed by Bolsheviks in February, 1918. 30000 Kokand's inhabitants became the victims of this rout, among them were both representatives of local population and of European.
In a rubric of one local newspaper there appeared an article titled "Kokand is the town of the deads now". Powerful national resistance movement of liberation which was called "basmachestvo" by Bolsheviks and liquidated by Soviet rule only in the 1930s became the reply to the rout of Turkestan autonomy.

If djadids' activity on the stage of enlightening was directed to unification of Turkestan's people, then in 1917-1918s one of important aims of Turkestan Autonomy became national interests' protection. M.Bekhbudi based the thesis that nobody and no authority would give people their independence voluntarily. "It is known from the history,-he noted,-that rights are conquered, but not given. Every nation, nationality can assert its rights, religion and politics only making its own efforts and uniting forces. We, Muslims, in particular, the Muslims of Turkestan, wish nobody to infringe on our religion and nation, and we, in our turn, have no intension to threaten anybody" [11].

\section{Conclusion}

In spite of its sad end national progressive movement, founded by djadids, promoted the rise of national consciousness, it played a vital part in coming into being and development of national ideology of liberation, and also formed the experience of national state system construction, embodied in full measure by Uzbekistan's gaining state independence.

\section{References:}

1. Mustafayeva SM (2009) "From the interrelationships history of Azerbaijan's and Turkestan's people in the struggle against the oppression of Russian Empire (the end of XIXthe beginning of XX) Baku "Elm va Tahsil"2009, p.168+the map, p.28-29.

2. (2008) OGU Bulletin №10 (92)/October, 2008.

3. (1893) Turkestan gazette. October 5,1893.

4. (2013) Bylye Gody.2013.Vol.27.№1

5. Behbudiy M (1906) "Hayir ul-umuri avsatuho/Khurshid”. October 11, 1906.

6. Balayev A (1998) Azerbaijani national movement in 1917-1918. Baku, "Elm", 1998, p. 280, p.33.
7. Behbudiy M (1917) Haq olinur, berilmas/ Khurriyat. July 13,1917

8. (1985) Programme documents of Muslim political parties (1917-1920).- Oxford,1985, p.33.

9. (2000) Turkestan at the beginning of XX c. To the history of national independence beginning. By guidance of Alimova D.A. Tashkent "Sharq", 2000, p.35.

10. (2000) Turkestan at the beginning of XX. To the history of national independence beginning. By guidance of Alimova D.A. Tashkent "Sharq", 2000, p.44.

11. Behbudiy M (1917) Haq olinur, berilmas/ Khurriyat. July $13,1917$. 